\title{
The Oil Price Crash of 2014: Implications for a Multi-Billion Dollar LNG Project
}

\author{
Uyiosa Omoregie \\ Lonadek Oil and Gas Consultants, Lagos, Nigeria \\ Email: uyiosaomoregie@yahoo.co.uk
}

Received 30 November 2015; accepted 18 December 2015; published 21 December 2015

Copyright @ 2015 by author and Scientific Research Publishing Inc.

This work is licensed under the Creative Commons Attribution International License (CC BY). http://creativecommons.org/licenses/by/4.0/

(c) (i) Open Access

\begin{abstract}
The price of oil is probably the single most important economic variable in the global economy. The rapid drop in price of oil in 2014 set analysts and commentators busy, trying to predict its trajectory and implications. More than $\$ 150$ billion of investments have been cancelled by oil companies in $\mathbf{2 0 1 5}$ due to the low price of oil, with more spending cuts to follow in 2016. The oil price decline was supposed to catalyze a transfer of wealth from oil-producing countries to oilconsuming countries. It was estimated that a $\mathbf{\$ 1 0}$-a-barrel fall in the oil price transfers around 0.5 percent of world GDP from oil exporters to oil importers. The recent oil price collapse has far-reaching implications for capital projects in the oil and gas industry. The impact of a fall in oil price is analyzed for a large capital investment project, involving the construction and operation of a liquefied natural gas (LNG) plant. The breakeven price (BEP) of oil for the project is determined.
\end{abstract}

\section{Keywords}

Oil Price, Global Economy, Mega Projects, Liquefied Natural Gas

\section{Introduction}

The price of oil is probably the single most important economic variable in the global economy. It is therefore not surprising to witness the global hysteria surrounding the 50 percent plunge in the price of oil during the second half of 2014.

The rapid drop in the price of oil in 2014 set analysts and commentators busy, trying to predict its trajectory and implications. Early analyses of the price plunge predicted a quick rebound in price: the low price was temporary, in the absence of a 2008-style global economic meltdown; the oil price would bounce back to $\$ 100$ per barrel. One analyst [1] concluded that the oil market was trapped in a negative bubble; the downward spiral of 
oil price over such a short space of time would be the opposite of the short-lived price hike that occurred in the first half of 2008 (a market distortion that was corrected the following year).

The Organization of Petroleum Exporting Countries (OPEC) meeting of 27 November 2014 was eagerly awaited. With the oil price in rapid decline, the oil industry (and much of the world economy) held its breath waiting for the decision OPEC would take. The 12-member cartel rejected calls for drastic action to cut their oil output. By keeping their production ceiling unchanged, OPEC members signaled that they were ready for a period of lower oil prices. OPEC's 27 November 2014 decision was a pivotal moment that had implications for the future of oil prices over the next 12 months. OPEC controls 40 percent of the world markets for oil and Saudi Arabia (OPEC's largest producer) produces about 10 million barrels of oil per day (more than 30 percent of OPEC's production). When asked why Saudi Arabia was deliberately pushing for lower oil prices, the Saudi oil minister replied that neither Saudi Arabia nor OPEC is capable of setting the price of oil—the price of oil is set by the markets. The oil minister's common-sense remark was a shock to analysts who have become all tooaccustomed to OPEC's intervention in the oil market. In fact, the oil market rarely behaves like a normal market (subject to the laws of demand and supply). But, as at the time of writing (November 2015), Adam Smith's invisible hand had replaced the visible hand of OPEC as the controlling force for the oil market.

According to The Economist [2], more than $\$ 150$ billion of investments have been cancelled by oil companies in 2015 due to the low price of oil, with more spending cuts to follow in 2016.

\section{Causes of Oil Price Shocks}

Bret-Rouzaut and Favennec [3], state that the price of oil is determined not by the speculation of traders, but by the balance of supply and demand. Other factors such as geopolitical events, stock levels of crude oil and products also play important roles from time to time. Speculation in the markets by oil traders only increases the volatility of oil price but does not affect the price level.

Hotelling's rule, derived from a 1931 paper written by Harold Hotelling [4], states that the price of an exhaustible (non-renewable) natural resource increases with the real interest rate or discount rate, when the cost of production is negligible. When the cost of production is significant, the rent or marginal cost price must increase with the discount rate. Hotelling's rule implies that a producer's most profitable (socially and economically) resource extraction/exploitation strategy is aligned with the price of the resource, which is determined by the marginal net revenue from the sale of the resource. As this price increases at the interest rate or discount rate, producers would need to exploit the resource as quickly as possible resulting in a fall in the price of the resource in the market. However, according to Hotelling's rule, if the price of the exhaustible resource increases at a higher rate, there would be a delay in the exploitation of the resource, producers would delay production to exploit a higher discount value at a later date.

Hotelling's rule does not explicitly place political factors into the pricing of a natural resource like oil. Giraud [5] attempts to link economic and political factors in the formation of petroleum prices. One characteristic feature of the petroleum industry is the political nature of its operations. A unique dynamic equilibrium petroleum price cannot be determined because actors that control significant low cost petroleum reserves do not always display "substantial economic rationality". As political preferences are expressed, an equilibrium price range is revealed. Only a range (or thresholds) of oil prices will make allowance for the link between political and economic and factors.

It is generally known that the price of oil affects macroeconomic performance, what is not common knowledge is the reverse causality from macroeconomic variables to oil prices revealed by researchers. Barksy and Kilian [6] argue that several factors are response for oil prices and exogenous political events in oil provinces such as the Middle East are but one of many factors. Similar political events will have different effects on the price of oil depending on the variations in oil-market demand conditions and general global macroeconomic conditions. This is a demand-driven account of oil price movement. Macroeconomic conditions affect the price of oil through demand channels: by shifting the demand for this commodity. Just like other industrial commodities, oil prices are sensitive to and respond to global economic forces.

Empirical studies demonstrate that oil demand shocks have had much more effect on the price of oil compared with oil supply shocks [7]:

...efforts to link crude oil price increases to crude oil production shortfalls alone are doomed to failure, given the overriding importance of shocks to the demand for crude oil not just in the most recent period but also dur- 
ing earlier oil price shock episodes...all major oil price shocks have coincided with capacity constraints in crude oil production and strong demand for oil...

The year 2014 was a dramatic year for the oil industry, but uncertainty and volatility should always be expected in this industry -it is the norm not the exception [8]. Dale [9] posits a 'new economics of oil' because the oil market has changed drastically over the past 10 - 15 years. The principles and beliefs concerning the oil market may no longer be relevant today when analyzing the current oil market. Dale revisits four principles, the first of which is the principle that oil is an exhaustible resource. Dale challenges Hotelling's rule which does not allow for the now-common reality that estimates of recoverable oil resources are constantly increasing, as new discoveries are made and as technology and knowledge improves. Hotelling's rule does not factor in uncertainty regarding the recovery rate from an oil reservoir or the possibility of new discoveries of oil. Hotelling's critical assumption is that the total stock of recoverable resource is given. But, approximately two barrels of oil have been added to the world's reserves for every barrel consumed. Total world proved reserved of oil in 2015 is more than double what was available in 1980. In addition, concerns about climate change will surely limit the amount of fossil fuel that will be extracted from the earth. So, for all intents and purposes, oil resources should be viewed as inexhaustible. With these new assumptions based on present reality, Hotelling's rule collapses along with the expectation that the relative price of oil will increase with time.

\section{Economic Effects of Oil Price Shocks}

The effect of a decline in oil prices on the global economy has been highlighted in the media [10] [11]. The oil price decline was supposed to catalyze a transfer of wealth from oil-producing countries to oil-consuming countries. It was estimated that a \$10-a-barrel fall in the oil price transfers around 0.5 percent of world GDP from oil exporters to oil importers. Increased spending by consumers in importing (mostly developed) countries will boost global output. It was estimated that a drop of $\$ 30$ in the oil price (prolonged for a year) would transfer more than $\$ 400$ billion from oil exporters to importers. China and Japan have large economies that spend more than other economies on net oil imports relative to GDP. Along with China and Japan, the Eurozone countries will also benefit a lot from the oil price drop. Countries like Nigeria and Venezuela that depend on crude oil for exports and government revenues were expected to be the most vulnerable.

Kilian [7] argues that although there exists a correlation between energy prices and macroeconomic outcomes, this correlation does not necessarily imply causation. The cost-share of oil in domestic output is known to be insignificant; hence, oil shocks should not really be interpreted as productivity shocks for real GDP. Again, a demand-driven analysis is proffered: higher energy prices appear to reduce discretionary income hence spending by consumers (due to higher energy bills), leading to a reduction in aggregate demand. But, the effect of a change in energy prices is bounded by the energy-share in consumption.

Adeniyi et al. [12] investigated the effect on the Nigerian economy of oil price shocks, specifically, the effects on macroeconomic variables, particularly real output. The effects of oil price shocks—surprisingly—were found to be insignificant: output, inflation and government revenue remained unchanged.

Likewise, the economic benefit to the US from the fall in oil prices in 2014 has been found to be negligible [13]. Analysis carried out revealed that the impact on economic activity in the US may even turn out to be negative if consumption grows slowly. This could be due to the fact that during the past few years the US has reemerged as a significant oil producer, with oil production constituting a bigger part of the US economy. Hence, rather than stimulate the economy (by acting as a tax cut for consumers), lower oil prices could reduce employment in the petroleum industry resulting in reduced consumption by those left out of work.

\section{Oil Price and Capital Investment (LNG Project)}

The impact of a fall in oil price is analyzed for a large capital investment project, involving the construction and operation of a liquefied natural gas (LNG) plant. The plant will be operated for 20 years. The breakeven price (BEP) of oil for the project is determined. Following Patsev et al. [14], the BEP will represent the oil price assumption that will make the project value-neutral i.e. make the net present value zero (NPV = 0). It then follows that any oil price scenario that increases the NPV of the project (NPV $>0$ ) will create value for the project. An oil price scenario that decreases the NPV to less than zero $(\mathrm{NPV}<0)$ will destroy value. The decision rule is to accept to undertake a project of this kind only if the NPV value is positive [15]. 


\subsection{The Model}

A spreadsheet-based (MS Excel) deterministic model is utilized for economic analysis of the project [14]-[16]. The model is a discounted cash flow (DCF) model. DCF models are popular with analysts for assessing the viability or economic merit of mega projects (projects worth $>\$ 1$ billion). The DCF model has three steps as illustrated in Figure 1 below. The NPV is the value of the sum of all future project cash flows (outflows and inflows), discounted back to the time of project sanction or final investment decision (FID) date, this is shown mathematically as:

$$
\mathrm{NPV}=\sum_{i=1}^{n} \frac{N C F}{\left(1+i_{d}\right)^{t}}
$$

where:

$N C F=$ Net cash flow;

$i_{d}=$ Discount factor;

$t=$ Time (years).

\subsection{Critical Assumptions}

Following Rodrik [17], this model's critical assumptions are those inputs into the model, whose modifications would result in a substantive difference in the model's conclusions. The model's critical assumptions are shown below:

Capital expenditure $(C A P E X)=\$ 16.5$ billion;

LNG plant capacity = 10 million tons per annum (mtpa);

Feed gas price $=\$ 2.0$ per million British thermal units (mmbtu);

$L N G$ sales price $=\$ 8.6$ per million British thermal units (mmbtu);

Oil price $($ Brent $)=\$ 80.0$ per barrel;

Plant operational life $=20$ years;

NPV discount rate $=10$ percent.

\subsection{Results}

The model's results show the project's NPV to be positive: discounted at a rate of 10 percent gives the value of $\$ 2367$ million (real terms 2015). Further analysis reveals the project to have a breakeven oil price of $\$ 56$ per barrel (see Figure 2).

\section{Conclusion}

The recent oil price collapse has far-reaching implications for capital projects in the oil and gas industry. Not surprisingly, it has been estimated that at least \$150 billion of investments were cancelled in 2015 [2]. The International Energy Agency (IEA) in November 2015 predicted an oil price of $\$ 80$ per barrel for the year 2020

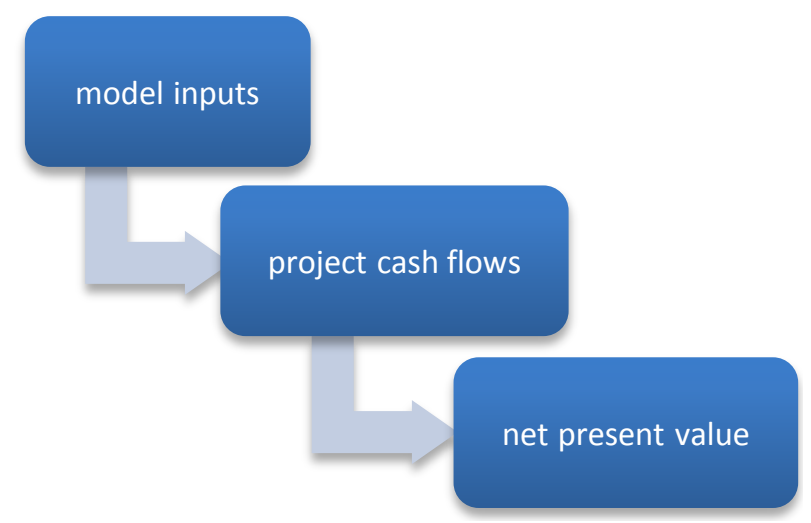

Figure 1. The three steps involved in a discounted cash flow (DCF) analysis. 


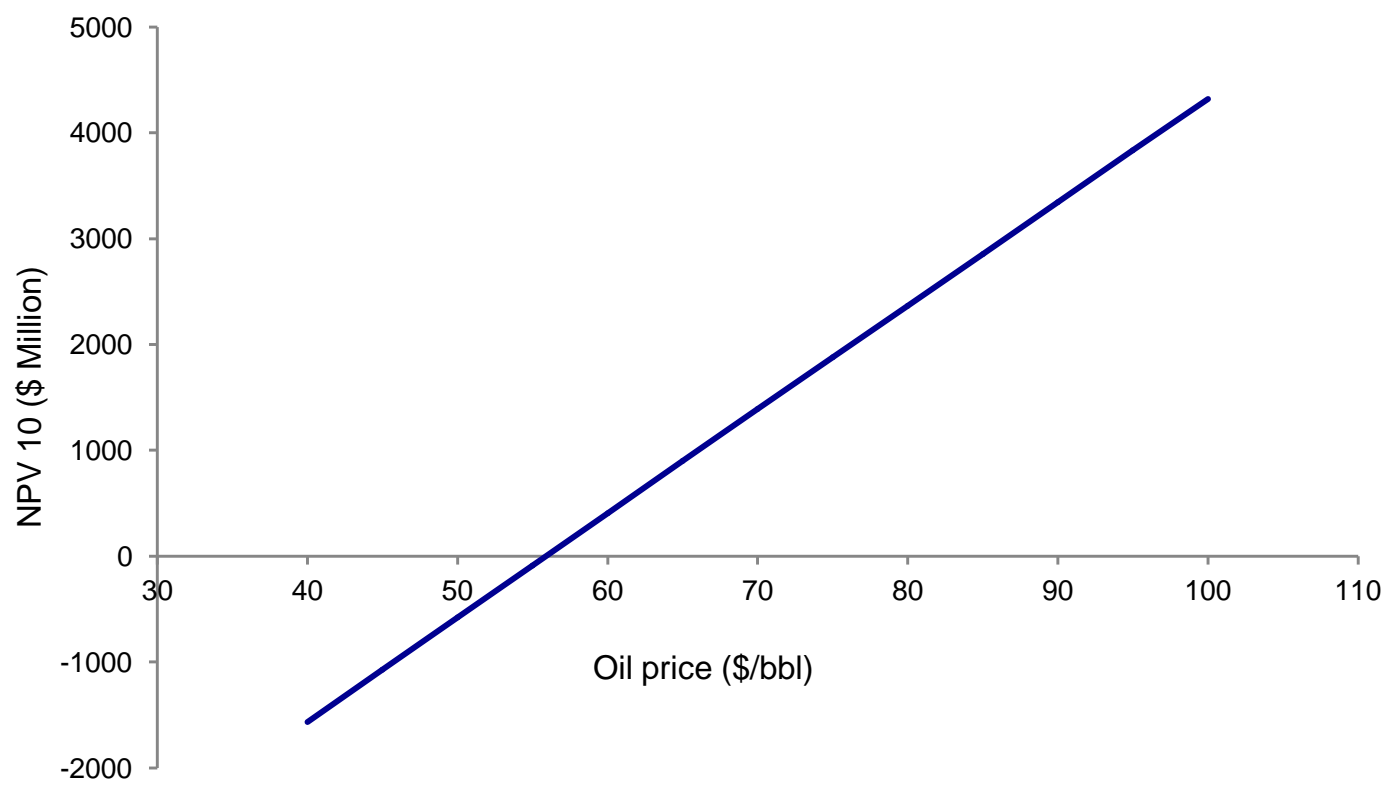

Figure 2. LNG project NPV sensitivity to oil price (breakeven oil price $=\$ 56 / \mathrm{bbl}$ ).

[18]. This IEA forecast was used as one of the critical assumptions for the current valuation of a multibilliondollar LNG project. The results revealed a positive NPV value, with a project breakeven price of $\$ 56$ per barrel. This breakeven price is higher than the current oil price of approximately $\$ 45$ per barrel at the time of writing. The implication for multi-billion LNG projects is that such projects will tend to be uneconomic if the oil price remains at the average 2015 price into the next decade and later.

\section{References}

[1] Kemp, J. (2014) Oil Market Is Trapped in a Negative Bubble. http://uk.reuters.com/article/oil-prices-kemp-idUKL6N0T43JD20141114

[2] The Economist (2015) The Oil Market Abnormally Normal. http://www.economist.com/news/finance/21678198-once-prices-are-responding-supply-and-demand-not-opec-why-ma $\underline{\text { rket }}$

[3] Bret-Rouzaut, N. and Favennec, J. (2011) Oil and Gas Exploration and Production. 3rd Edition, Edition Technip, Paris.

[4] Hotelling, H. (1931) The Economics of Exhaustible Resources. Journal of Political Economy, 39,137-175. http://dx.doi.org/10.1086/254195

[5] Giraud, P. (1995) The Equilibrium Price Range of Oil. Energy Policy, 23, 35-49. http://dx.doi.org/10.1016/0301-4215(95)90764-X

[6] Barsky, R. and Kilian, L. (2004) Oil and the Macroeconomy since the 1970s. Journal of Economic Perspectives, 18, 115-134. http://dx.doi.org/10.1257/0895330042632708

[7] Kilian, L. (2008) The Economic Effects of Energy Price Shocks. Journal of Economic Literature, 46, 871-909. http://dx.doi.org/10.1257/jel.46.4.871

[8] Dale, S. (2015) Energy in 2014 After a Calm Comes the Storm. http://www.bp.com/content/dam/bp/pdf/energy-economics/statistical-review-2015/bp-statistical-review-of-world-energ y-2015-spencer-dale-presentation.pdf

[9] Dale, S. (2015) New Economics of Oil. http://www.bp.com/content/dam/bp/pdf/speeches/2015/new-economics-of-oil-spencer-dale.pdf

[10] The Economist (2014) Cheaper Oil Both Symptom and Balm. http://www.economist.com/news/finance-and-economics/21625819-oil-price-tumbling-good-or-bad-news-world-econo my-both

[11] Financial Times (2014) Price of Crude Oil How Low Can It Go. http://www.ft.com/intl/cms/s/0/de459900-6664-11e4-8bf6-00144feabdc0.html\#axzz3sKDnaXsx 
[12] Adeniyi, O., Oyinola, A. and Omisakin, O. (2011) Oil Price Shocks and Economic Growth in Nigeria: Are Thresholds Important? OPEC Energy Review, 35, 308-333. http://dx.doi.org/10.1111/j.1753-0237.2011.00192.x

[13] Arora, V. (2015) Oil Prices and the U.S. Economy: Where Is the Boom? Economics Discussion Papers, 48, Kiel Institute for the World Economy. http://www.economics-ejournal.org/economics/discussionpapers/2015-48

[14] Paltev, S., O’Sullivan. F., Lee, N., Agarwal, M., Li, X. and Fylakto, N. (2013) Natural Gas Monetization Pathways for Cyprus: Interim Report-Economics of Project Development Options, MIT Energy Initiative. Massachusetts Institute of Technology, Cambridge, MA.

[15] Lazson, N. and Ikiensikimama, S. (2013) Economic Analysis of Liquefied Natural Gas Floating Production Storage and Offloading Plant (LNG FPSO) Using Probabilistic Approach. Advances in Petroleum Exploration and Development, 5, 42-50.

[16] Mian, M.A. (2011) Project Economics and Decision Analysis, Vol. 1: Deterministic Models. 2nd Edition, PennWell Publishing Co., Tulsa.

[17] Rodrik, D. (2015) Economics Rules. Oxford University Press, Oxford, United Kingdom.

[18] International Energy Agency (2015) World Energy Outlook. http://www.iea.org/bookshop/700-World_Energy_Outlook_2015 